\title{
Comparison of Fatty Acid Compositions of Commercial Fish and Fish By- Products Oils Used in Fish Feed Industry in Turkey
}

\author{
Kutsal Gamsız ${ }^{1, a, *}$, Ali Yıldırım Korkut ${ }^{1, b}$, Aysun Kop ${ }^{1, c}$ \\ ${ }^{I}$ Department of Aquaculture, Fisheries Faculty, Ege University, 35040 Bornova/İzmir, Turkey
}

*Corresponding author

A R T I C LE INF O

Research Article

Received : 19/08/2019

Accepted : 10/10/2019

\section{Keywords:}

Fish oil

Fatty acids

Fish by-products

Feed

Fish nutrition
A B S T R A C T

Fats have a function in transmitting the necessary fatty acids to fish as well as being an energy source in fish nutrition. In particular, high-chain unsaturated fatty acids are needed for feeding saltwater fish. In this study, the fatty acid composition of fish oils obtained from some whole-body fish and fish by-products used in the fish-feed industry in Turkey was determined and compared with each other. Accordingly, SFA (Saturated fatty acids) ratios were in the range of $15.57-33.38 \%$ in the oils obtained from the whole-body fish and in the range of $16.3-31.89 \%$ in the oils from fish by-products; MUFA (Monounsaturated fatty acids) ratios were in the range of $24-38.69 \%$ in the oils obtained from the whole-body fish and in the range of $25.81-47.57 \%$ in the oils from fish by-products; PUFA (Polyunsaturated fatty acids) ratios were in the range of $31-36.73 \%$ in the oils obtained from the whole-body fish and in the range of $33.54-36.78 \%$ in the oils from fish by-products. Given DHA (docosahexaenoic acid) and EPA (eicosapentaenoic acid) ratios which are among the most important PUFAs for nutrition, it was determined that DHA ratios were in the range of $14.08-19.10 \%$ in the oils obtained from the whole-body fish and in the range of $3.55-15.28 \%$ in the oils from fish byproducts, whereas EPA ratios were in the range of $8-9.89 \%$ in the oils obtained from the whole-body fish and in the range of $2.63-15.28 \%$ in the oils from fish by-products.

Türk Tarım - Gıda Bilim ve Teknoloji Dergisi 7(11): 1941-1946, 2019

\section{Türkiye Balık Yemi Sektöründe Kullanılan Ticari Balık ve Balık Yan Ürünleri Yağlarının, Yağ Asitleri Kompozisyonlarının Karşılaştırılması}

\begin{tabular}{|c|c|}
\hline \multicolumn{2}{|c|}{$\begin{array}{l}\text { M A K A L E B İ L C } \\
\text { Araştırma Makalesi }\end{array}$} \\
\hline Geliş & : 19/08/2019 \\
\hline Kabul & : 10/10/2019 \\
\hline
\end{tabular}

\section{Anahtar Kelimeler:}

Balık yağ 1

Yağ asitleri

Balık yan ürünleri

Yem

Balık besleme
Ö Z

Balık beslemede yağlar enerji kaynağı olmasının yanı sıra gerekli olan yağ asitlerinin balıklara iletilmesinde de görev alırlar. Özellikle, deniz balıklarının beslenmesinde yüksek zincirli doymamış yağ asitlerine ihtiyaç vardır. Bu çalışmamızda Türkiye balık yemi sektöründe kullanılan bazı tüm vücutlu balıklardan ve balık yan ürünlerinden elde edilen balık yağlarının yağ asidi kompozisyonları tespit edilmiş ve birbiri ile karşılaştırılmaları yapılmıştır. Elde edilen sonuçlara göre tüm vücutlu balıklardan elde edilen yağlarda SFA (Doymuş yağ asitleri) oranlarının \%15,57-33,38 arasında olduğu, balık yan ürünlerinden elde edilen yağlarda ise \%16,3-31,89 arasında değiştiği saptanmıştır. Ayrıca tüm vücutlu balıklardan elde edilen yağlarda MUFA (Tekli doymamış yağ asitleri) oranlarının \%24-38,69 arasında, balık yan ürünleri yağlarında ise \%25,81-47,57 arasında değiştiği, tüm balıklardan elde edilen yağlarda PUFA (Çoklu doymamış yağ asitleri) oranlarının \%31-36,73 arasında, balık yan ürünleri yağlarında ise \%33,54-36,78 arasında değiştiği tespit edilmiştir. Besleme açısından en önemli PUFA'lar dan olan DHA (docosahexaenoic asit) ve EPA (eicosapentaenoic asit) oranlarına baktığımızda, DHA oranlarının tüm balıklardan elde edilen yağlarda \%14,08-19,10 arasında, balık yan ürünleri yağlarında ise \%3,55-15,28 arasında değiştiği, EPA oranlarının ise tüm balıklardan elde edilen yağlarda \%8-9,89 arasında, balık yan ürünleri yağlarında ise $\% 2,63-15,28$ arasında değiştiği tespit edilmiştir. 


\section{Introduction}

Fatty acids are the nutritional active ingredients of the fats. The ratios and compositions of fatty acids determine the chemical and physical properties of fats and also have a direct effect on the growth and health of the organism. Many different methodologies are used to classify fatty acids. For the classification, it is taken into account that the number of carbon atoms, the number of single and double bonds between carbon atoms, the position of these bonds and the fact that these bonds are saturated or unsaturated. Unsaturated fatty acids are the most important fatty acids for nutrition. Unsaturated fatty acids are also divided into two groups as monounsaturated (MUFA) and polyunsaturated fatty acids (PUFA). Among the polyunsaturated fatty acids, the ones with more than twenty carbon atoms and more than three double bonds are termed highly unsaturated fatty acids (HUFA) (Hoşsu et al.,2012; Ratnayake and Galli,2009).

Polyunsaturated fatty acids are also divided into two groups as omega-3 and omega-6. Fish and mammals cannot synthesize $n-3$ and n- 6 fatty acids in their body unless there is a suitable precursor in their diet. Therefore, it is essential for health and growth that the food contains the appropriate fatty acids in the necessary amount. Aquatic organisms often require n-3 fatty acids, while terrestrial organisms mostly require $n-6$ fatty acids (Cho, 1983; Wang et al. 2017).

The most important fatty acids for fish nutrition are linolenic acid (LNA, 18:3n-3) and linoleic acid (LA, 18:2n6) from PUFA group, and docosahexaenoic acid (DHA, 22:6n-3), eicosapentaenoic acid (EPA, 20:5n-3) and arachidonic acid (ArA, 20:4n-6) from HUFA group. Because these fatty acids are essential fatty acids for normal development and reproduction. LNA and LA, which are polyunsaturated fatty acids, are important fatty acids because they can be converted to DHA, EPA, and ArA by most freshwater fish. Linolenic acid can be converted to DHA and EPA, while linoleic acid can be converted to ArA (Sargent, 1999).

Polyunsaturated fatty acids, which are very important for fish nutrition, should be given to fish together with the feed. The requirement of fish for these fatty acids varies according to species. Freshwater fish require the $\mathrm{C} 18$ series PUFA group like LNA, LA, while saltwater fish species require EPA, DHA, and ArA. While EPA, DHA and ArA requirements are low in species that meet their needs from fatty acids of the $\mathrm{C} 18$ series, the fatty acid requirements increase during the larval state. Besides, the essential fatty acid requirements of mature fish also increase because these fatty acids play an important role in egg and larval development (Tocher, 2010).

In order to meet the requirements of energy and essential fatty acids in fish nutrition, fish oil in saltwater fish feeds, and fish oil and vegetable oils in freshwater fish feeds are used. Fish oils are generally produced from some pelagic fish species and fish processing wastes. Fish oil production was 856 thousand tons in 2016 worldwide (SEAFISH, 2016). 26\% of the produced fish oil is obtained from fish processing wastes (Jackson ve Newton, 2016). Because fish oil production is mostly linked to fish caught from nature, fish oil prices differ according to the change in the amount of fish caught. The average fish oil price was 413 US dollars/tons in 1981, while this price increased to 1808 US dollars/tons in 2015 (FAO, 2016). Most of the nutrition studies performed in recent years seek oils that can be used in place of most fish oils, as the prices are increased, and the fish species used in the production of fish oil may also be used for human nutrition. Vegetable oils take the first place in these substitution studies. Although in the studies there has not found an oil source to completely replace the fish oil, studies have shown that $70 \%$ of vegetable oils have been used instead of fish oil, especially in freshwater fish nutrition, however, fish oil is still needed as the main source for saltwater fish nutrition (Hixson, 2014; Torrecillas et al., 2017).

It is a fact that fish oil production is indispensable, depending on the importance of fish oil for the nutrition of aquatic organisms. Therefore, the importance of oil production from processing wastes is also increasing. According to the IFFO 2012 data, it has been reported that the prices of fish meal and oil may be decreased by $8-14 \%$ within the next 15 years as the aquaculture is increased, and aquaculture may become more economical (World Bank, 2013).

In this study, fatty acid compositions of some fish and fish by-product oils used in the fish feed industry in our country have been identified. These compositions are thought to assist in the calculation of the amount of fatty acids required during the preparation of the feed formulas.

\section{Material and Method}

Oil samples were obtained from fish oil production and marketing companies to the fish feed sector in our country. Black Sea fish oil (BSFO, mixture of anchovy +sprat) sprat oil (SO), anchovy oil (AO), Norwegian fish oil (NFO) directly obtained from whole fish, and sea bream-sea bass processing waste oil (SBWO), salmon waste oil (SWO), tuna processing waste oil (TWO) were collected from the corresponding firms and stored at $+4{ }^{\circ} \mathrm{C}$ until analysis. Fatty acids analysis was carried out in Akvatek Aquaculture Feed Analysis Laboratory. Agilent Technologies 782A model gas chromatography equipment was used for fatty acid analysis. Agilent HP-88 capillary column was used as the column, hydrogen was used as the carrier gas and Supelco 37 Component Fame Mix was used as fatty acid standard. Composition analyses of fatty acids were performed using the EU regulation 2568/91 method (David et al., 2005). When preparing the methyl esters according to this method, 0.25 grams from each oil sample were weighted and $2 \mathrm{ml}$ of $\mathrm{N}$-hexane and $2 \mathrm{~mL}$ of Methanolic $\mathrm{KOH}$ (prepared by dissolving $1.2 \mathrm{~g}$ of $\mathrm{KOH}$ in $100 \mathrm{~mL}$ of Methanol) were added and the capped tubes were vortexed for 30 seconds. After waiting for a while, the tubes were centrifuged at $4000 \mathrm{rpm}$ for 2 minutes to allow separation of the phases and the supernatant was filtered through previously prepared glass wool and anhydrous sodium sulphate pastor pipette. $1 \mu \mathrm{l}$ of the filtrate was taken with an injector and provided to GC. Analyses results of the oils were given as \%.

\section{Results}

The results of the fatty acid compositions and classes of the analysed oils are provided in Table 1. 
Table 1 Fatty acid compositions and fatty acid classes of the samples analyzed (\% fat)

\begin{tabular}{|c|c|c|c|c|c|c|c|}
\hline & BSFO & $\mathrm{AO}$ & SO & $\mathrm{NFO}$ & SBWO & SWO & TWO \\
\hline Butyric acid, C4:0 & 1.78 & 1.47 & 2.59 & 2.15 & 2.01 & 1.02 & 2.74 \\
\hline Caprylic acid, C8:0 & 0 & 0 & 0 & 0 & 0 & 0 & 0 \\
\hline Capric acid, C10:0 & 0 & 0 & 0 & 0 & 0 & 0 & 0 \\
\hline Lauric acid, C12:0 & 0.03 & 0.07 & 0.04 & 0 & 0 & 0 & 0 \\
\hline Tridecanoic acid, C13:0 & 0 & 0 & 0 & 0 & 0 & 0 & 0 \\
\hline Myristic acid C14:0 & 5.3 & 5.61 & 5.76 & 4.76 & 3.25 & 2.18 & 4.08 \\
\hline Pentadecanoic acid, C15:0 & 0 & 0 & 0 & 0 & 0 & 0 & 0 \\
\hline Palmitic acid, C16:0 & 17.66 & 0 & 16.40 & 16.77 & 16.28 & 8.42 & 15.65 \\
\hline Heptadecanoic acid, C17:0 & 1.32 & 1.39 & 1.50 & 1.15 & 0.91 & 0 & 1.095 \\
\hline Stearic acid, C18:0 & 3.98 & 3.55 & 2.04 & 3.89 & 2.84 & 2.36 & 4.8 \\
\hline Arachidic acid, C20:0 & 0.93 & 0.91 & 0.84 & 0.86 & 0.51 & 0.47 & 2.81 \\
\hline Heneicosanoic acid, C21:0 & 1.40 & 1.71 & 2.05 & 1.14 & 0.59 & 0.66 & 0 \\
\hline Behenic acid, C22:0 & 0.25 & 0.17 & 0.24 & 0.15 & 0.2 & 0.40 & 0 \\
\hline Tricosanoic acid, C23:0 & 0.45 & 0.47 & 0.55 & 0.39 & 0.37 & 0.72 & 0.71 \\
\hline Lignoseric acid, C24:0 & 0.26 & 0.2 & 0.25 & 0.23 & 0.07 & 0.06 & 0 \\
\hline Total SFA & 33.38 & 15.57 & 32.28 & 31.50 & 27.06 & 16.3 & 31.89 \\
\hline Myristoleic acid, C14:1 & 0.81 & 0.84 & 0.88 & 0.7 & 0.49 & 0.15 & 0.475 \\
\hline Palmitoleic acid, C16:1 & 5.6 & 17.03 & 7.16 & 4.93 & 5.43 & 2.92 & 6.11 \\
\hline Oleic acid, C18:1n9c & 21.15 & 20.25 & 14.97 & 22.13 & 28.68 & 43.76 & 18.72 \\
\hline Cis-11-eicosenoic acid C20:1 & 0.63 & 0.10 & 0.61 & 0.09 & 0.14 & 0.16 & 0 \\
\hline Erucic acid, C22: $\ln 9$ & 0.22 & 0.23 & 0.11 & 0.19 & 0.78 & 0.43 & 0 \\
\hline Nervonic acid, C24:1 & 0.17 & 0.23 & 0.26 & 0.1 & 0.095 & 0.13 & 0.505 \\
\hline Total MUFA & 28.65 & 38.69 & 24.00 & 28.14 & 35.63 & 47.57 & 25.81 \\
\hline Linelelaidic acid, 18:2n9t & 0.34 & 0.45 & 0.15 & 0.34 & 0.315 & 0.15 & 0.91 \\
\hline Linoleic acid, C18:2n6c & 3.02 & 2.15 & 2.43 & 8.81 & 11.38 & 14.18 & 1.66 \\
\hline Gama-linolenic acid, C18:3n6 & 1.35 & 1.02 & 1.37 & 1.87 & 1.69 & 5.82 & 0.68 \\
\hline Linolenic acid, $\mathrm{C} 18: 3 \mathrm{n} 3$ & 0.63 & 1.49 & 0.68 & 0.82 & 2.26 & 3.8 & 1.77 \\
\hline Cis-11,14-eicosedienoic acid, C20:2 & 0.2 & 0.22 & 0.17 & 0.17 & 0.11 & 1.01 & 0 \\
\hline Cis-13,16-docosadienoic acid,C22:2 & 0.12 & 0.05 & 0.13 & 0.11 & 0.26 & 0.09 & 0 \\
\hline Cis-8,11,14-eicosetrienoic acid,C20:3n6 & 0.25 & 0.31 & 0.7 & 0.33 & 0 & 0 & 0 \\
\hline Cis-11,14,17-eicosetrienoic acid,C20:3n3 & 2.07 & 2.23 & 1.54 & 1.89 & 0.79 & 2.59 & 0 \\
\hline Arachidonic acid, C20:4n6 & 0 & 0 & 0 & 0 & 0 & 0 & 3.78 \\
\hline EPA, C20:5n3 & 8.92 & 9.89 & 9.80 & 8.01 & 4.81 & 2.63 & 12.69 \\
\hline DHA, C22:6n3 & 14.08 & 17.43 & 19.10 & 14.37 & 11.91 & 3.55 & 15.28 \\
\hline n-3 PUFA & 23.63 & 28.81 & 29.59 & 23.20 & 18.98 & 9.98 & 29.74 \\
\hline n-6 PUFA & 4.37 & 3.17 & 3.8 & 10.68 & 13.07 & 20 & 6.12 \\
\hline Total PUFA & 31.0 & 35.25 & 36.10 & 36.73 & 33.54 & 33.84 & 36.78 \\
\hline Total Fatty Acid & 92.99 & 89.51 & 92.39 & 96.38 & 96.24 & 97.71 & 94.48 \\
\hline
\end{tabular}

When SFA ratios are taken into consideration, it was observed that SFA ratios were in the range of 15.57$33.38 \%$ in the oils produced using the whole body and in the range of $16.3-31.89 \%$ in the oils of fish by-products, and the lowest amount of saturated fatty acid was found in anchovy oil with a ratio of $15.17 \%$. The highest amount of saturated fatty acid was found in Black Sea oil with a ratio of $33.38 \%$. The saturated fatty acid that has the highest ratio among all oils is palmitic acid.

In the case of MUFA ratios, it was determined that MUFA ratios were in the range of $24-38.69 \%$ in the oils produced using the whole body and in the range of 25.81 $47.57 \%$ in the oils of fish by-products, but the lowest monounsaturated fat ratio was found in sprat oil with a ratio of $24 \%$, whereas the highest ratio was found in Salmon Processing waste oils with a ratio of $47.57 \%$. Oleic acid has been found to be the highest fatty acid in all oils.

In the case of PUFA ratios, it was determined that PUFA ratios were in the range of $31-36.73 \%$ in the oils produced using the whole body and in the range of 33.54$36.78 \%$ in the oils of fish by-products, the lowest ratio was found in Black Sea oil and the highest ratio was found in tuna processing waste oil with a ratio of $36.78 \%$. When LNA ratios are taken into consideration, it was seen that the lowest ratio of $0.63 \%$ was found in Black Sea oil, whereas the highest ratio of $3.8 \%$ was seen in salmon processing waste oil. In the case of LA ratios, the lowest linoleic ratio of $1.66 \%$ was found in tuna processing waste oil, whereas the highest ratio of $14.18 \%$ was found in salmon processing waste oil.

Given DHA and EPA ratios which are among the most important PUFAs for nutrition, it was determined that DHA ratios were in the range of $14.08-19.10 \%$ in the oils produced using whole body and in the range of 3.55$15.28 \%$ in the oils from fish by-products, whereas EPA ratios were in the range of $8-9.89 \%$ in the oils produced using the whole body and in the range of $2.63-15.28 \%$ in the oils from fish by-products. It was observed that the highest DHA ratio of $19.10 \%$ was found in the sprat oil and the lowest rate of $3.55 \%$ was found in the salmon processing waste oil. It was determined that the highest EPA ratio was found in anchovy oil with a ratio of $9.89 \%$, 
while the lowest EPA ratio of $2.63 \%$ was found in salmon processing waste oil among oils.

In general, when the n-3 fatty acids were examined, it was determined that the lowest ratio of $9.98 \%$ was found in salmon processing waste oil, whereas the highest ratio of $29.74 \%$ was found in tuna processing waste oil. While the lowest ratio among the total n- 6 fatty acids was found in the anchovy oil with a ratio of $3.7 \%$, whereas the highest ratio of n-6 fatty acids was found in the processing waste oil with a ratio of $13.07 \%$.

According to the analysis results, ArA was found only in tuna oil at a ratio of $3.78 \%$, but not in any other oil.

\section{Discussion}

Aquaculture is among the fastest-growing food sectors in our country as in the world. Turkey aquaculture production reached 253.395 tons in 2016 and 151.794 tons of this production is from marine, and 101.601 tons from freshwater fish. 355.387 tons of feed were used in aquaculture in our country according to 2013 data. It is thought that although the ratios of the fat used in the feeds vary, it is around $35 \%$ of the produced feed amount, i.e. around 35.000 tons. The fact that $59.9 \%$ of the fish grown in our country are saltwater fish indicates that the requirement for fish oil is high (BSGM, 2017; Korkut et al., 2017).

Many fish species such as anchovy, horse mackerel, sardines, sprat, haddock, and herring are used in the production of fish meal and oils made using whole fish. In the production in our country, anchovy and sprat are used mostly in the Black Sea Region (Emir et al., 2012).

It has been reported that in the studies the fatty acid composition of fish depends on the species of fish, its nutrition characteristics, and the season it is caught (Çelik et al., 2005; Selmi et al., 2008). Therefore, the fatty acid composition of the fish has also an effect on the oil which was directly produced from the fish.

The total SFA values of all the oils analyzed in our study were found to vary between $15.57 \%$ and $33.38 \%$, the MUFA values vary between $24 \%$ and $47.57 \%$, and the PUFA values range between $31 \%$ and $36.78 \%$. Giogios et al., (2009) examined fatty acid compositions of different fish oils and found that SFA values varied between $19.1 \%$ and $28.3 \%$, MUFA values varied $26.3 \%$ and $48.3 \%$, and PUFA values ranged from $28.7 \%$ to $44 \%$. Our results are similar to Giogios et al. (2009) results.

In fish oils, besides the fatty acid classes, another important issue is the amount of n-3 long chain fatty acids (DHA and EPA) in these oils.

According to the study results, the DHA content of oils produced from all fish is higher than the oils made from processing wastes. The main reason for this is that such oils are derived from fish species called pelagic and fatty fish. Among the processing waste oils, the highest DHA was obtained in the tuna waste processing oil. Alkio et al. (2000) reported in their study that $18.3 \%$ of tuna oil was DHA. The tuna oil used in this study is an oil produced in the canning factory and a processing waste oil as in our study. A DHA content of $15.28 \%$ found in our study is similar to that of Alkio et al. (2000). Many researchers report DHA contents of tuna oils at different ratios. However, these values generally range from $9.3 \%$ to $25 \%$.
It has been reported that these differences are caused by differences in the nutritional environment of tuna fish (Haraldsson and Kristinsson, 1998; Halldorsson et al., 2003; Giogios et al., 2009; Susena et al., 2014).

When the ratios of EPA, one of the major fatty acids, are examined, the highest EPA ratio is found in the tuna oil. Previous studies have reported that the EPA ratios in tuna oil are between $2.7 \%$ and $7.8 \%$, and the ratio of $12.69 \%$ in our study is higher than the reported values. However, Selmi et al. (2008) examined oil and fatty acid compositions in the waste visceral organs of tuna fish caught at different times of the year from the same region and reported that the fat content varied between $1.49 \%$ and $14.26 \%$ and the EPA values varied between $4 \%$ and $10 \%$. Since it is not known when the tuna wastes used in the study are obtained, it is thought that the EPA value obtained is determined as a new value in terms of tuna fish oil.

In addition to being an energy source, fats are involved in many metabolic functions through the fatty acids therein. Particularly highly unsaturated fatty acids such as DHA, EPA and ArA are involved in the structure and maintenance of cell membranes and function as precursors for the secretion of steroid hormones and prostaglandins. For this reason, these fatty acids are the fatty acids that are essential for the survival of other living organisms as in fish. The ability of freshwater fish to convert linolenic acid to DHA and EPA that are highly unsaturated fatty acids and linoleic acid to ArA indicate that the use of terrestrial fats is possible for the nutrition of freshwater fish. However, to meet the requirement in saltwater fish, it is necessary to add sources with high HUFA content to fish feeds (Sargent, 1999, Tocher, 2015). In the studies on the reduction of fish oils in saltwater fish species, there is obtained very different results depending on the species and the type of oil used for replacement. It has been reported that in some studies the ratio of replacement may be at a ratio of $2 / 3$ and that this will not have a negative impact on fish production, whereas it has been reported in some studies that the use of terrestrial resources instead of fish oil has a negative effect and HUFA ratios of fish meat are adversely affected even if not during growing (MongeOrtiz et al., 2017; Bou et al. 2017; Sprague et al., 2017).

In general, reducing the use of fish oils in fish feeds is essential for sustainable aquaculture. However, to meet the requirements of fish for highly unsaturated fatty acids, valuable new resources should be found. Aquatic organisms are the first sources that come to mind again. Especially phytoplankton and zooplankton species (copepods), krill species, and single cell organism are sources of highly unsaturated fatty acids which are thought to be obtained from aquatic areas. In addition, in the transgenic studies, it has been attempted to transfer genes involved in the synthesis of long chain fatty acids in marine algae to terrestrial oilseed plants and to provide DHA and EPA from these plants (Bou et al., 2017; Shepherd et al., 2017; Jobling, 2016; Tocher, 2015; Sprague et al., 2016; Sprague et al. 2017); Linder et al., (2010) reported that some of the phytoplankton species contain $14.97 \%$ of DHA and $9.28 \%$ of EPA, whereas Krill species contain $15.8 \%$ to 28.3 of DHA and 6.7-31.6\% of EPA.

When sources of new fatty acids are sought, the importance of processing wastes usage should not be forgotten. The use of fish processing wastes in fish oil 
production is essential for sustainable aquaculture. Salmon processing wastes are used in the production of 150.000 tons of fish oil. Using of Salmon oil is prohibited in salmon feed for various reasons, this oil is used to produce valuable fish such as sea bream and sea bass (Kobayashi et al. 2015; Shepherd et al., 2017).

As seen in our study, oils produced from sea bream-sea bass or tuna processing wastes have better HUFA and PUFA content than salmon processing waste oil. As a result, increasing the use of fish processing waste in the production of oil and meal in our country is essential for the sustainability of our country's aquaculture.

\section{Acknowledgment}

This study was supported by Ege University Scientific Research Projects Coordination Unit (Project No. 2016SÜF034). The authors wish to thank Akvatek company for their valuable supports regarding analyses of fatty acids.

\section{References}

Alkio M, González C, Jäntti M, Aaltonen O. 2000. Purification of polyunsaturated fatty acid esters from tuna oil with supercritical fluid chromatography JAOCS, Journal of the American Oil Chemists' Society, 77 (3): 315-321. Doi: 10.1007/s11746-000-0051-3

Bou M, Berge G., Baeverfjord G, Sigholt T, Østbye T, Romarheim O, Ruyter B. 2017. Requirements of n-3 very long-chain PUFA in Atlantic salmon (Salmo salar L): Effects of different dietary levels of EPA and DHA on fish performance and tissue composition and integrity. British Journal of Nutrition, 117(1): 30-47. Doi: 10.1017/S0007114516004396

BSGM. 2017. T.C. Gida, Tarım ve Hayvancilık Bakanlığı, Balıç̧ılık ve $\mathrm{Su}$ Ürünleri Genel Müdürlüğü. http://www.tarim.gov.tr/sgb/Belgeler/SagMenuVeriler/BSG M.pdf (25.01.2018)

Cho CY. 1983. Nutrition and fish health. In: Meyer, F.P., Warren, J.W., Carey, T.G. (Eds.) A guide to integrated fish health management in the Great Lakes basin. Great Lakes Fishery Commission, Michigan. Special Publication 83-2. pp. 63-74.

Çelik M, Diler A, Küçükgülmez A. 2005. A comparison of the proximate compositions and fatty acid profiles of zander (Sander lucioperca) from two different regions and climatic conditions, Food Chemistry, Volume 92, (4): 637-64. Doi: 10.1016/j.foodchem.2004.08.026

David F, Sandra P, Vickers AK. 2005. Column Selection for the Analysis of Fatty Acids Methyl Esters; Agilent Technologies, Agilent Application Notes 59893760EN. Santa Clara, CA, USA.

Emir M, Karadağ HO, Ege F, Ceyhan V. 2012. Fish Oil and Fish Meal Production in Turkey: Situation, Bottlenecks and Solutions. 10. Ulusal Tarım Kongresi, 5-7 Eylül, Konya

FAO. 2016. Fish meal and Fish oil. Commodity Statistics Uptade. Rome, Italy.

Giogios I, Grigorakis K, Nengas I, Papasolomondos S, Papaioannou N, Alexis MN. 2009. Fatty acid composition and volatile compounds of selected marine oils and meals. J. Sci. Food Agric., 89: 88-100. Doi: 10.1002/jsfa.3414

Haraldsson GG, Kristinsson B. 1998. Separation of eicosapentaenoic acid and docosahexaenoic acid in fish oil by kinetic resolution using lipase. J Am Oil Chem Soc. 75: 1551-1556. Doi: 10.1007/s11746-998-0093-9

Halldorsson A, Kristinsson B, Glynn C. 2003. Separation of EPA and DHA in Fish Oil by Lipase-Catalyzed Esterification with Glycerol J. Amer. Oil Chem. Soc. Volume 80(9): 915-927. Doi: 10.1007/s11746-003-0796-8
Hixson SM. 2014. Fish nutrition and current issues in aquaculture: the balance in providing safe and nutritious seafood, in an environmentally sustainable manner. J. Aquac. Res. Dev., 5:234 p.. Doi: 10.4172/2155-9546.1000234.

Hoşsu B, Korkut AY, Kop A. 2012. Balık Besleme ve Yem Teknolojisi 1. Ege Üniversitesi Su Ürünleri Fakültesi Yayınları, Yayın No:50, Bornova

Jackson A., Newton RW. 2016. Project to model the use of fisheries by-products in the production of marine ingredients with special reference to omega3 fatty acids EPA and DHA. Special Report, IFFO and University of Stirling, 14 pages https://www.iffo.net/system/files/Report\%20IoA\%20IFFO\% 20project\%20Final_0.pdf

Jobling M. 2016. Fish nutrition research: past, present and future. Aquacult Int. 24:767-786. Doi: 10.1007/s10499-014-9875-2

Korkut AY, Kop,A, Sayg1 H, Göktepe Ç, Yedek Y, Kalkan T. 2017. General Evaluation of Fish Feed Production in Turkey. Turkish Journal of Fisheries and Aquatic Sciences. 17: 223229. Doi: 10.4194/1303-2712-v17_1_25

Linder M, Belhaj N, Sautot P, Tehrany EA. 2010. From Krill to Whale: an overview of marine fatty acids and lipid compositions. OCL. 17-4, 194-204. Doi: 10.1051/ocl.2010.0328

Kobayashi M, Misangi S, Batka M, Vannuccini S, Dey MM, Anderson JL. 2015. Fish To 2030: The Role And Opportunity For Aquaculture. Aquaculture Economics and Management, 19:282-300. Doi: 10.1080/13657305.2015.994240

Monge-Ortiz R, Tomás-Vidal A, Rodriguez-Barreto D, MartínezLlorens S, Pérez JA, Jover-Cerdá M, Lorenzo L. 2017. Replacement of fish oil with vegetable oil blends in feeds for greater amberjack (Seriola dumerili) juveniles: Effect on growth performance, feed efficiency, tissue fatty acid composition and flesh nutritional value. Aquaculture Nutrition. 24:605-615. Doi: 10.1111/anu.12595

Ratnayake WMN, Galli C. 2009. Fat and Fatty Acid Terminology, Methods of Analysis and Fat Digestion and Metabolism: A Background Review Paper. Ann Nutr Metab, pp: 55:8-43. Doi: 10.1159/000228994

Sargent J, Bell G, McEvoy L, Tocher D, Estevez A. 1999. Recent developments in the essential fatty acid nutrition of fish, Aquaculture, Volume 177, Issues 1-4, Pages 191-199. Doi: 10.1016/S0044-8486(99)00083-6

SEAFISH. 2016. Fishmeal and fish oil facts and figures. (http://www.seafish.org/media/publications/SeafishFishmeal andFishOilFactsandFigures_201612.pdf) (25.01.2018)

Selmi S, Mbarki R, Sadok S. 2008. Seasonal Change of Lipid and Fatty Acid Composition of Little Tuna Euthynnus Alletteratus-By-Products. Nutrition and health. 19:189-194. Doi: 10.1177/026010600801900305

Shepherd CJ, Monroig O, Tocher DR. 2017. Future availability of raw materials for salmon feeds and supply chain implications: The case of Scottish farmed salmon. Aquaculture, 467: 49-62. Doi: 10.1016/j.aquaculture.2016.08.021

Sprague M, Betancor MB, Tocher DR. 2017. Microbial and genetically engineered oils as replacements for fish oil in aquaculture feeds. Biotechnol Lett.39: 1599-1611. Doi: 10.1007/s10529-017-2402-6

Sprague M, Dick JR, Tocher DR. 2016. Impact of sustainable feeds on omega-3 long-chain fatty acid levels in farmed Atlantic salmon, 2006-2015. Sci. Rep. 6, 21892; Doi: 10.1038/srep21892. Doi: 10.1038/srep21892

Susena SH, Saraswati Hayati S, Izaki AF. 2014. Fatty acid composition of some potential fish oil from production centers in Indonesia. Oriental Journal of Chemistry. 30(3): 975-980. Doi: 10.13005/ojc/300308

Tocher DR. 2010. Fatty acid requirements in ontogeny of marine and freshwater fish. Aquacult. Res. 41: 717-732. Doi: 10.1111/j.1365-2109.2008.02150.x

Tocher DR. 2015. Omega-3 long-chain polyunsaturated fatty acids and aquaculture in perspective. Aquaculture, 449, pp. 94-107. Doi: 10.1016/j.aquaculture.2015.01.010 
Torrecillas S, Robaina L, Caballero MJ, Calandra G, Karalazos V, Kaushik S, Izquierdo MS. 2017. Combined replacement of fishmeal and fish oil in European sea bass (Dicentrarchus labrax): production performance, tissue composition and liver morphology. Aquaculture, 474: 101-112. Doi: 10.1016/j.aquaculture.2017.03.031
Wang Y, Li M, Filer K, Xue Y, Ai Q, Mai K. 2017. Replacement of fish oil with a DHA-rich Schizochytrium meal on growth performance, activities of digestive enzyme and fatty acid profile of Pacific white shrimp (Liptopenaeus vannamei) larvae. Aquac. Nutr. Vol:23(5): 1113-1120. Doi: 10.1111/anu.12479

World Bank. 2013. Fish to 2030: Prospects for Fisheries and Aquaculture. World Bank Report Number 83177-GLB. 81 pages. 